\title{
Pola Asuh Orang Tua Terhadap Anak Generasi Alfa Dalam Meningkatkan Keterampilan Sosial
}

\author{
Canny Christine \\ STT Baptis Indonesia \\ Email: canny.ch.cc@gmail.com \\ Karnawati \\ STT Baptis Indonesia \\ Email: karnawati@stbi.ac.id \\ Debora Nugrahenny $C$ \\ STT Baptis Indonesia \\ Email:debora@stbi.ac.id
}

\begin{abstract}
Generation Alfa is the generation born in 2010 to 2025 where technological developments have advanced so that everything can be obtained easily. However, children's enjoyment of gadgets causes children to become more self-centered, anti-social and less confident, making it difficult to get along directly and difficult to be sensitive to other people's feelings and withdraw from social groups. In this case, the family has the task of laying the foundation for children's education, including providing basic social education. This study aims to determine the description of children's social skills and parenting patterns of Generation Alpha children (aged 7-10 years) at the Banyumanik Indonesian Baptist Church. This study uses a qualitative design as an approach that fits the existing problems. Based on the results of the study, it was found that most of the children had social skills towards themselves, others, and academic success. Meanwhile, social skills towards the home environment are still minimal. In terms of parenting, most parents apply democratic parenting which includes love, discipline, teaching, and role models.
\end{abstract}

Keywords: Alfa Generation; Social Skills; Parenting

\begin{abstract}
Abstrak
Generasi Alfa adalah generasi yang lahir pada tahun 2010 hingga tahun 2025 di mana perkembangan teknologi sudah maju sehingga segala sesuatu dapat diperoleh dengan mudah. Akan tetapi kesenangan anak dengan gawai menyebabkan anak menjadi pribadi yang lebih mementingkan diri sendiri, anti-sosial dan kurang percaya diri sehingga sulit untuk bergaul secara langsung serta sulit untuk peka terhadap perasaan orang lain serta menarik diri dari kelompok sosial. Dalam hal ini, keluarga memiliki tugas sebagai peletak dasar bagi pendidikan anak termasuk memberikan pendidikan dasar sosial. Penelitian ini bertujuan untuk mengetahui gambaran keterampilan sosial anak dan pola asuh orang tua anak Generasi Alfa (usia 7-10 tahun) di Gereja Baptis Indonesia Banyumanik. Penelitian ini menggunakan
\end{abstract}


rancangan kualitatif sebagai pendekatan yang sesuai dengan permasalahan yang ada. Berdasarkan hasil penelitian, ditemukan bahwa sebagian besar anak telah memiliki keterampilan sosial terhadap diri sendiri, orang lain, dan keberhasilan akademik. Sedangkan keterampilan sosial terhadap lingkungan rumah masih minim. Dari segi pola asuh, sebagian besar orang tua menerapkan pola asuh demokratis yang di dalamnya meliputi kasih, disiplin, pengajaran, dan teladan.

Kata-kata kunci: Anak Generasi Alfa; Keterampilan Sosial; Pola Asuh Orang Tua

\section{PENDAHULUAN}

Generasi alfa merupakan tema penelitian yang sudah umum bagi kaum akademis. Berikut beberapa penelitian yang membahas hal tersebut: Fadlurrohin menyimpulkan bahwa generasi alfa adalah generasi yang tidak dapat lepas dari gawai, kurangnya sosialisasi dan daya kreativitas, hal ini disebabkan oleh karena mereka lahir bersamaan dengan masa Industri 4.0 (Fadlurrohim et al., 2020). Ia memberi rekomendasi bahwa peran keluarga sangat penting dalam proses tumbuh kembang anak. Rohimin sependapat, bahwa perlu adanya reposisi pendidikan keluarga untuk generasi ini (Rohimin, 2020). Generasi alfa menikmati berbagai kemudahan yang diakibatkan teknologi. Sebagai contoh mudahnya menerima berbagai informasi melalui web browser seperti google chrome, firefox, opera, yang terkoneksi dengan internet. Anthonetha melihat bahwa segala kemudahan tersebut mengakibatkan dekadensi moral, sehingga perlu adanya rumusan metode pendisipinan anak yang berorientasi pada kasih (Tfuakani et al., 2021).

Berdasarkan pengamatan pada anakanak generasi alfa Gereja Baptis Indonesia (GBI) Banyumanik, kesibukan mereka bermain gawai cenderung mengalahkan interaksi sosial bersama teman sebaya.

Akibatnya terjadi penurunan kemampuan atau keterampilan sosial anak dalam bentuk interaksi sosial dan empati kepada sesama.

Keluarga sebagai salah satu dari tripusat pendidikan, yang memberikan pendidikan pertama dan utama kepada anak, memiliki tugas sebagai peletak dasar bagi pendidikan anak termasuk memberikan pendidikan dasar sosial (Darmadi, 2019, p. 84). Anak akan belajar tentang dasar-dasar perilaku di dalam lingkup keluarga melalui model para anggota keluarga terutama orang tua. Cara orang tua memperlakukan anak dalam bentuk pola asuh juga akan mempengaruhi sikap dan perilaku anak (Tridhonanto \& Agency, 2014, pp. 2-3). Oleh karena itu, penelitian ini hanya akan berfokus untuk mengetahui bagaimana pola asuh orang tua terhadap 
generasi alfa dalam menyikapi tantangan perubahan keterampilan sosial anak. Sehingga penelitian ini dapat menambah khasanah penelitan-penelitian sebelumnya.

Berdasarkan latar belakang masalah yang telah dikemukakan di atas, maka pertanyaan penelitiannya adalah: bagaimana gambaran keterampilan sosial anak dan bagaimana pola asuh orang tua anak generasi alfa di GBI Banyumanik dalam meningkatkan keterampilan sosial anak? Sedangkan tujuan penelitian adalah untuk mengetahui gambaran keterampilan sosial anak generasi alfa dan mengetahui pola asuh orang tua anak generasi alfa di GBI Banyumanik dalam meningkatkan keterampilan sosial anak.

\section{METODE PENELITIAN}

Penelitian ini menggunakan pendekatan kualitatif deskriptif. Penelitian ini dirancang untuk dapat menemukan dan mengetahui pola asuh orang tua terhadap anak generasi alfa (usia 7-10 tahun) dalam meningkatkan keterampilan sosial anak. Partisipan berjumlah delapan orang tua dari anak generasi alfa di GBI Banyumanik. Metode pengumpulan data dengan wawancara semi terstruktur. Prosedur pengolahan data dilakukan dengan mendeskripsikan jawaban dari hasil wawancara, catatan lapangan, dan dokumentasi. Kemudian dianalisis dengan cara mengurutkan data ke dalam kategori pertanyaan. Setelah itu peneliti melakukan interpretasi data dengan cara menafsirkan hasil analisis sehingga diperoleh gambaran pola asuh orang tua terhadap anak generasi alfa dalam meningkatkan keterampilan sosialnya.

\section{HASIL DAN PEMBAHASAN}

\section{Anak Generasi Alfa}

Generasi Alfa (Alfa Generation) adalah sekumpulan manusia yang lahir pada periode 2010-2025. Istilah generasi alfa pertama kali dicetuskan oleh Mark McCrindle, seorang analis sosial dan demografi dari grup peniliti McCrindle berkebangsaan Australia. Adanya pemberian label "Generasi Alfa" dikarenakan generasi ini akan memulai hidup pada tahap baru yang dilambangkan dengan abjad Yunani pertama yaitu $\alpha$ (alfa). Dikala generasi sebelumnya menghadapi krisis terorisme, resesi ekonomi global, dan perubahan iklim, maka sepanjang pembentukan generasi alfa, ancamanancaman tersebut dimungkinkan telah surut (McCrindle, 2020). Sebuah situs resmi grup peneliti, McCrindle (mccrindle.com) memuat sebuah artikel penelitian berjudul "What comes after Generation Z? Introducing Generation Alfa", yang memperkenalkan Generasi Alfa sebagai generasi terbaru setelah Generasi Z (Santoso, 2017, p. 11). 
Akrabnya Generasi Alfa dengan teknologi mendatangkan peluang sekaligus tantangan bagi orang dewasa dan orang tua. Peluang dari teknologi mendatangkan manfaat bagi kehidupan sehari-hari anak, antara lain: (1) mudah mendapat informasi dari berbagai sumber; (2) mempermudah komunikasi sebab banyak aplikasi penunjang yang tidak terhalang ruang dan waktu; (3) menstimulasi kreativitas; (4) memudahkan proses belajar sebab internet menawarkan berbagai program belajar yang dapat di akses secara mandiri untuk meningkatkan kemampuan dan ketrampilan (Kementrian Pendidikan dan Kebudayaan, 2018, pp. 10-12). Sebaliknya tantangan secara fisik ditandai dengan adanya (1) gangguan kesehatan mata sebab ketajaman cahaya dan jarak yang terlalu dekat saat menatap layar gawai; (2) masalah tidur sebab tidak teraturnya jam dan lama waktu untuk tidur; (3) kesulitan konsentrasi yang dapat mempengaruhi kemampuan anak dalam belajar dan menurunkan hasil prestasi belajar; (4) ketidak seimbangan perkembangan motorik kasar dan halus sebab kurangnya mengerakkan seluruh anggota tubuh; (5) gangguan pencernaan. Akibatnya berat badan anak terlalu gemuk bahkan ada pula terlalu kurus. Sedangkan dari segi perkembangan bahasa dan keterampilan sosial anak akan mengalami gangguan sebagai berikut: (1) tertundanya per- kembangan bicara dan bahasa sebab anak lebih banyak berinteraksi dengan gawai dan aplikasi pendukung; (2) berkurangnya waktu berkualitas bersama keluarga; (3) terbatasnya pergaulan sosial sebab anak lebih suka bermain sendiri dan sulit berinteraksi dengan komunitas yang berbeda dengan dirinya (Kementrian Pendidikan dan Kebudayaan, 2018, pp. 10-12). Akrabnya anak dengan teknologi juga menumbuhkan pribadi yang lebih mementingkan diri sendiri, anti-sosial dan kurang percaya diri sehingga sulit untuk bergaul secara langsung serta sulit untuk peka terhadap perasaan orang lain (Kementrian Pendidikan dan Kebudayaan, 2019, p. 9).

\section{Gambaran Keterampilan Sosial Anak Generasi Alfa GBI Banyumanik}

Menurut Combs dan Slaby, keterampilan sosial didefinisikan sebagai kemampuan berinteraksi dengan orang lain dalam konteks sosial dengan cara-cara khusus yang dapat diterima dan pada waktu bersamaan dinilai menguntungkan atau saling menguntungkan (Merrell \& Gimpel, 2014, p. 4). Osland dalam Agusniatih mengatakan bahwa keterampilan sosial adalah kemampuan memelihara hubungan dengan membangun jaringan berdasarkan kemampuan untuk menemukan titik temu serta membangun hubungan dengan baik (Agusniatih et al., 
2019, p. 72). Dari beberapa pengertian di atas dapat disimpulkan bahwa keterampilan sosial adalah kemampuan individu yang diperoleh melalui proses belajar guna membangun dan memelihara hubungan melalui interaksi yang efektif sehingga keberadaannya dapat diterima oleh orang lain.

Tuhan Yesus-pun menunjukkan keterampilan sosial dengan memafaatkan berbagai situasi dan lingkungan belajar yang bervariasi, sehingga dimanapun Ia berada, selalu memungkinkan terjadinya proses belajar yang bermakna (Karnawati et al., 2019). Di samping itu Yesus juga memberi contoh sebuah komunikasi yang runtut dan sistematis ketika berbicara dengan perempuan Samaria (Yohanes 4:142) dengan menggunakan pendahuluan, penyampaian materi ajar, sebuah kesimpulan, dan menunggu suatu tanggapa dari orang yang diajar-Nya (Karnawati \& Darmawan, 2020). Dengan demikian dapat disimpulkan bahwa keterampilan sosial penting bagi kehidupan manusia untuk membangun interaksi dengan orang lain, sehingga kebutuhannya dapat terpenuhi serta keberadaannya dapat diterima oleh orang lain.

Adapun bentuk keterampilan sosial anak menurut Hurlock meliputi meniru orang yang dikagumi, bersaing dan bekerjasama dengan teman bermain, simpati, empati, dukungan sosial, berbagi sesuatu, dan perilaku akrab (Hurlock, 1997, p. 118). Mclnytre menyebutkan bahwa keterampilan sosial anak meliputi tingkah laku dan interaksi positif dengan teman, perilaku yang sesuai di dalam kelas, mampu mengatasi konflik dan kemarahan, dan mampu mengatasi konflik dengan orang lain (Kurniati, 2016). Sedangkan Caldarella dan Merrell menjabarkan bentuk keterampilan sosial berdasarkan beberapa aspek, yaitu: 1) hubungan dengan teman sebaya (peer relations) yang ditandai dengan kemampuan anak untuk memberikan pujian, menawarkan bantuan dan mengundang atau mengajak teman untuk bermain bersama. 2) kemampuan memanajemen diri (self-management skill) yang berkenaan dengan kemampuan anak dalam mengatur diri sendiri dan mengontrol emosi dengan baik. 3) kemampuan akademik (academic skill) adalah perilaku yang berhubungan dengan keaktifan anak dalam kelas. 4) kepatuhan (compliance) berkenaan dengan kemampuan anak untuk memenuhi permintaan orang lain yang ditandai dengan mengikuti petunjuk atau instruksi, mematuhi aturan, memberikan respon yang baik terhadap kritik, dan menyelesaikan tugas. 5) kemampuan assertif (assertion skill) adalah ke-mampuan anak untuk mengomunikasikan sesuatu yang diharapkan baik dalam menyampaikan perasaan maupun pemikiran secara jujur 
namun tetap menjaga dan menghargai perasaan orang lain. Jadi dapat disimpulkan, bentuk keterampilan sosial adalah keterampilan yang berhubungan dengan diri sendiri, orang lain termasuk teman sebaya, lingkungan, dan keberhasilan akademik.

Adapun hasil penelitian menunjukkan bahwa gambaran keterampilan sosial anak generasi alfa di GBI Banyumanik sebagai berikut: 1) Sebagian besar anak memiliki keterampilan sosial terhadap diri sendiri. Hal ini terlihat dari semua anak melakukan tanggung jawab yang diterimanya. Sebagian besar anak juga mampu mengekspresikan perasaan saat meng-hadapi sebuah konflik atau masalah dengan lingkungan sosial. Semua anak mampu menerima konsekuensi atas kesalahan yang diperbuat diri sendiri. 2) Berkenaan dengan keterampilan sosial terhadap orang lain/teman, semua anak berani berkata "tidak" terhadap ajakan tindakan yang tidak tepat dari orang lain. Sebagian besar anak membangun hubungan dengan teman di lingkungan sekolah, suka bermain di luar rumah, mampu berkomunikasi dengan orang yang baru dikenal, memberikan atau menawarkan bantuan kepada orang yang mengalami kesulitan, dan menunjukkan sikap positif saat teman berhasil dalam perlombaan. Empat anak membangun hubungan dengan teman dilingkungan rumah. Tiga anak lebih suka mengajak teman bermain terlebih dahulu. Tiga anak mampu bersikap positif terhadap pendapat orang lain. Dalam membangun hubungan pertemanan, terdapat hambatan internal yaitu kepribadian anak dan eksternal yaitu perbedaan pendapat dalam bermain, perbedaan keyakinan iman, penerimaan label negatif dari teman. 3) Berkenaan dengan keterampilan sosial terhadap lingkungan, sebagian besar anak menjaga kebersihan di lingkungan sekolah. Sebagian kecil anak memiliki inisiatif untuk menjaga kebersihan lingkungan rumah. Dalam menjaga kebersihan di lingkungan rumah anak memiliki hambatan yaitu kurangnya kesadaran dari diri sendiri. Hal itu dibuktikan dengan anak yang harus diingatkan orang tua untuk menjaga kebersihan rumah. 4) Berkenaan dengan keterampilan sosial terhadap keberhasilan akademik, sebagian besar anak memiliki keterampilan sosial terhadap keberhasilan akademik. Hal itu dibuktikan dengan semua anak hadir dalam kelas, berani menjawab pertanyaan yang diberikan oleh guru, mengikuti instruksi guru, dan aktif terlibat dalam kerja kelompok atau diskusi. Sebagian besar anak mampu mengerjakan tugas secara mandiri. Enam dari delapan anak mendapat peringkat di kelas. Dalam mencapai keberhasilan akademik, ada hambatan yang dialami oleh anak yaitu perilaku 
negatif dari teman-teman kelas terhadap anak dan perasaan bosan terhadap tugas sekolah.

\section{Pola Asuh Orang Tua Anak Generasi}

\section{Alfa GBI Banyumanik}

Pola asuh kepada anak dalam masyarakat Israel pertama kali merupakan tugas rumah tangga (Harmadi \& Karnawati, 2020, p. 75). Dengan demikian pola asuh adalah sebuah proses tindakan dan interaksi yang dipelopori orang tua kepada anak dalam bentuk perhatian dan pengarahan anak hingga menuju tahap dewasa. Dari pengertian di atas dapat disimpulkan bahwa pola asuh orang tua adalah kekonsistenan perilaku dan interaksi antara orang tua dengan anak baik dalam mendidik, merawat dan mempersiapkan diri anak hingga dewasa berupa pemenuhan kebutuhan fisik, psikologi maupun pengajaran nilai dan norma.

Orang tua sebagai pembawa pengaruh dalam kehidupan anak memiliki tanggungjawab untuk mengasuh, melindungi dan membimbing anak dari bayi hingga dewasa, serta memenuhi kebutuhan anak atas rasa cinta, disiplin dan nilai. Amsal 22:6 mengatakan bahwa orang tua memiliki tanggungjawab untuk mendidik anak, mengajarkan hikmat supaya anak terlindung dari dosa. Pendidikan akan mempersiapkan diri anak untuk menjalani hidup di hari depan. Sifat- sifat baik yang telah diajarkan oleh orang tua akan tertanam dalam diri anak dan akan melekat seumur hidup.

Yusuf dan Maria adalah gambaran dari orang tua yang bertanggungjawab dalam mengasuh anak. Yesus bertumbuh tidak hanya secara jasmani namun juga rohani. Yesus secara fisik bertumbuh semakin besar. Sedangkan secara rohani Yesus semakin bertambah hikmat-Nya, dan semakin dikasihi Allah dan sesama (Lukas 2:52). Yusuf sebagai seorang ayah berkebangsaan Yahudi menyadari perannya untuk memberikan pendidikan kepada anak sebagaimana tradisi Perjanjian Lama dalam Ulangan 6:5-9 (Shema Israel) yang merupakan proses pembelajaran memorisasi (Darmawan, 2019) dimana keluarga harus mengajarkan anak-anak tentang Allah melalui kehidupan sehariharinya (Rantesalu, 2018).

Bilangan Research Center juga menyatakan bahwa anak yang dibesarkan dan tinggal dalam keluarga dimana orang tua adalah pengikut Kristus sungguhsungguh cenderung memiliki tingkat pengharapan dan ketahanan iman dua kali lipat dibandingkan dengan anak yang dibesarkan dan atau tinggal dalam keluarga dimana kedua orang tuanya sama sekali bukan pengikut Kristus sungguh-sungguh (Irawan et al., 2018, p. 67). Hal ini menunjukkan bahwa peran orang tua Kristen sangat penting dalam pertumbuhan 
kepribadian dan iman seorang anak. Pola pengasuhan orang tua pada saat sekarang akan membawa pengaruh dalam kehidupan anak di masa datang baik dari segi kepribadian maupun iman.

Pola asuh memiliki dua dimensi pembentuk yakni dimensi kontrol dan dimensi kehangatan. Dimensi kontrol berhubungan dengan sejauh mana orang tua mengharapkan dan menuntut kematangan anak serta tingkah laku yang bertanggungjawab dari anak. Dimensi kehangatan berhubungan dengan tingkat respon orang tua terhadap kebutuhan anak dalam penerimaan dan dukungan. Dalam pandangan Baumrind, ada lima aspek yang berperan dalam dimensi kontrol yakni 1) Pembatasan (Restrictiveness), 2) Tuntutan (Demandingeness), 3) Sikap ketat (Strictness), 4) Campur tangan (Intrusiveness), dan 5) Kekuatan yang sewenang-wenang (Arbitrary exercise of power) (Baskoro, 2019). Sedangkan dalam dimensi kehangatan aspek-aspek yang berperan yakni 1) Perhatian orang tua terhadap kesejahteraan anak, 2) Respon orang tua terhadap kebutuhan anak, 3) Meluangkan waktu dalam kegiatan bersama, 4) Menunjukkan rasa antusias pada tingkah laku dan keberhasilan anak, dan 5) Peka akan emosi anak (Baskoro, 2019).

Adapun konsep dimensi kontrol dan kehangatan telah membentuk beberapa gaya pengasuhan. Baumrind mengidentifikasi adanya tiga gaya pola asuh yakni pola asuh otoritatif, otoriter dan permisif. Sedangkan menurut Maccoby dan Martin, tinggi dan rendah dari dimensi tersebut membentuk empat gaya pengasuhan kepada anak yaitu pola asuh otoriter, pola asuh permisif, pola asuh pengabaian (uninvolved), dan pola asuh demokratis (Laible et al., 2019, p. 42).

Pola Asuh Otoriter. Dalam pola asuh ini orang tua memiliki standar yang tinggi baik dalam aturan, keputusan dan tuntutan. Sikap tidak bersahabat dengan anak dan sangat membatasi pertukaran pendapat. Namun tidak selalu pola asuh ini terkesan kasar sebab keluarga otoriter dapat juga berbentuk keluarga "kalem" yang menerapkan nilai-nilai tradisional berupa menasehati dan menegur secara terus menerus.

Pola Asuh Permisif. Pola asuh permisif memiliki dimensi kontrol rendah dan dimensi kehangatan tinggi. Orang tua cenderung memanjakan, tidak banyak menuntut, dan jarang mendisiplin anak. Keinginan anak dengan cepat akan dipenuhi (Santosa, 2015, p. 106). Anak cenderung dibiarkan untuk mengatur aktivitasnya sendiri dan orang tua kurang tegas dalam menerapkan peraturan ataupun tindakan kedisiplinan. Orang tua selalu menerima dan membenarkan perilaku anak sehingga semua keputusan anak justru 
lebih banyak mempunyai peranan daripada orang tua (Susanto, 2015, p. 29). Dampak dari pola asuh permisif bagi perkembangan sosial yaitu anak menjadi agresif, sukar menyesuaikan diri dengan lingkungan, sukar menjalin relasi dan bekerjasama dengan orang lain, kurangnya rasa peduli, serta kurang dapat mengendalikan diri sehingga emosi kurang stabil.

Pola Asuh Pengabaian (Uninvolved). Pola asuh dengan dimensi kontrol dan kehangatan yang sama rendahnya. Orang tua tipe ini tidak memberikan kontrol dan tidak juga memberikan perhatian kepada anak. Bentuk perilaku dalam pola asuh ini tergolong sebagai bentuk penelantaran. Orang tua hanya sebatas menjalan tugasnya sebagai orang tua dengan memberi nafkah, fasilitas kehidupan dan pendidikan formal namun jarang memenuhi kebutuhan psikologi anak (Santosa, 2015). Orang tua pola ini cenderung tidak tahu banyak aktifitas anak oleh karena memiliki sedikit waktu bertemu dan jarang berbincang-bincang serta hampir tidak memedulikan pendapat anak (Musman, 2020, p. 10). Nampaknya pola asuh ini mirip dengan pola asuh permisif, namun pola asuh pengabaian menuruti keinginan anak bukan atas dasar kasih sayang melainkan dengan tujuan agar anak bisa segera menjauh dari orang tua (Baskoro, 2019, p. 29). Standar ataupun ketentuan apapun juga tidak diberikan kepada anak. Semua hal dibebaskan tanpa ada pengontrolan. Dampak dari pola asuh pengabaian (uninvolved) bagi perkembangan sosial yaitu anak menjadi tidak percaya diri, sukar mengekspresikan perasaan dengan tepat, bertindak sesuai keinginan diri sendiri baik di rumah maupun di sekolah dan memiliki empati yang rendah. Ketidakpercayaan diri anak disebabkan adanya pikiran curiga bahwa diri anak ditolak oleh orang lain. Sedangkan sikap orang tua yang mengabaikan atau tidak peduli dengan anak menyebabkan anak cenderung tidak peduli dengan perasaan orang lain dan bertindak sesuai keinginan diri sendiri. Dalam pola asuh ini anak tidak mengerti tindakan yang salah dan benar sebab tidak adanya figur dari orang tua (Baskoro, 2019).

Pola Asuh Demokratis. Pola asuh demokratis adalah pola asuh yang dianggap paling ideal diantara lainnya. Pola asuh ini memiliki dimensi kontrol dan kehangatan yang sama tinggi. Orang tua tidak hanya mendidik dengan kedisplinan, akan tetapi juga dengan kasih sayang sehingga kebutuhan fisik dan psikologi anak tercukupi. Orang tua juga tidak sungkan untuk mengekspresikan kasih sayangnya kepada anak. Sedangkan dari segi anak, ia tidak hanya wajib menuruti perintah orang tuanya, akan tetapi juga 
diberi hak untuk berpendapat (Baskoro, 2019). Anak yang dididik dengan pola asuh demokratis berkembang menjadi pribadi yang penuh dengan inisiatif, mampu menyesuaikan diri, tidak mudah takut, mampu membangun relasi dan kerjasama, serta percaya diri. Selain daripada itu, pola asuh ini juga mendorong anak untuk bersikap dewasa. Kedewasaan tersebut dapat dilihat melalui kemampuan anak untuk menghargai pendapat orang lain sekalipun berbeda pendapat, menerima kritik dengan terbuka, memiliki rasa tanggung jawab, dan tidak bersikap egois atau ingin menang sendiri. Jikalaupun anak menerima suatu perilaku kedisplinan, maka anak akan tahu bahwa kedisiplinan tersebut dilandaskan kasih sayang.

Berikut merupakan unsur-unsur pola asuh yang perlu diterapkan dalam lingkungan keluarga:

Kasih. Alkitab mengatakan bahwa kasih merupakan hukum terutama dan pertama. Dalam Perjanjian Lama hukum kasih dijabarkan dalam sepuluh perintah Allah yang terdiri dari empat untuk Allah dan enam untuk sesama manusia. Demikian pula dalam Perjanjian Baru, Yesus mengatakan: "Kasihilah Tuhan, Allahmu, dengan segenap hatimu dan dengan segenap jiwamu dan dengan segenap akal budimu. Itulah hukum yang terutama dan yang pertama. Dan hukum yang kedua, yang sama dengan itu, ialah:
Kasihilah sesamamu manusia seperti dirimu sendiri." (Matius 22:34-40)

Yesus adalah teladan dalam hal mengasihi. Pelayanan-Nya di dunia digerakkan oleh rasa belas kasihan. Bukti kasih-Nya semakin jelas dengan kerelaanNya untuk mati di kayu salib menjadi tebusan bagi banyak orang. Anak adalah anugerah yang diberikan oleh Allah kepada umat manusia. Kasih harus diperoleh seorang anak sejak mulanya, saat anak berada dalam kandungan ibu. Oleh karena itu orang tua perlu memberikan pelajaran tentang kebenaran Firman Tuhan sejak dini melalui metode-metode yang tepat dengan keteraturan dan prinsip kasih sayang (Karnawati \& Suseno, 2021). Selain itu orang tua perlu menanamkan identitas yang kuat kepada anak sehingga orangorang diluar tidak akan dengan mudah mempengaruhi, menentukan kepribadian dan mencetak ke dalam pola tertentu yang negatif. Identitas tersebut dapat ditanamkan dengan cara rela berkorban baik secara waktu dan perhatian untuk memahami perasaan anak sebagaimana Yesus selama melakukan pelayanan-Nya di dunia turut menyelami perasaan orang lain (Yohanes 11:32-36; 2:1-11). Orang tua perlu meluangkan waktu untuk berkomunikasi dengan anak dengan bahasa cinta (Manurung, 2021). Orang tua mendengarkan pendapat dan berusaha memahami perasaan anak tanpa terburu- 
buru mendisiplin. Pelukan hangat dan kasih sayang dari orang tua dapat lebih berarti bagi anak.

Disiplin. Disiplin termasuk cara Allah untuk membawa anak sedini mungkin kepada Allah dan menyesuaikan hidup dengan gambar-Nya. Ibrani 12:6 berkata "Karena Tuhan menghajar orang yang dikasihi-Nya, dan Ia menyesah orang diakui-Nya sebagai anak." Allah juga mendisiplin anak-anak rohani-Nya yaitu orang-orang percaya. Baik anak-anak maupun orang tua harus mengerti bahwa Allah memerintahkan orang tua untuk mendisiplin anak-anak. Disiplin merupakan sebuah tindakan ketaatan kepada Allah dari orang tua yang sungguhsungguh mengasihi anak. Dalam kenyataannya, persoalan utama dalam mendisiplin anak adalah orang tua yang mendahulukan perasaan dan pemikiran manusiawi daripada perintah Allah. Orang tua mengganggap bahwa memanjakan dan menuruti segala keinginan anak-anak tanpa mempertimbangkan dampak kedepan adalah bentuk menyatakan kasih. Sesungguhnya saat orang tua bertindak demikian tanpa sadar sedang memberi dorongan kepada anak untuk bersifat egois dan memikirkan diri sendiri. Perlu di ingat bahwa tujuan orang tua Kristen adalah pertama supaya pribadi anak mengenal dan menyerahkan diri kepada Tuhan Yesus dan kedua supaya kehidupan anak mencerminkan karakter Kristus.

Pengajaran. Dalam membesarkan anak, memberi teladan dan mengajar harus berjalan bersama. Setiap orang tua memberi teladan tentang gaya hidup dan mengajarkan pula suatu prinsip, baik dan buruk. Pengajaran yang diberikan oleh orang tua penting sekali untuk membentuk karakter dan kepribadian anak. Eunike, ibu Timotius, mengajar dengan sangat baik. Sejak kecil Timotius telah dididik oleh Eunike menurut Kitab Suci (2 Timotius 3:14-15). Sehingga Timotius bertumbuh dewasa dan menjadi seorang pemimpin, pengkhotbah, pengajar serta perintis jemaat baru. Pengajaran harus datang dari orang tua dan Firman Tuhan harus menjadi dasar pengajaran. Dampak dari pengajaran Firman Tuhan yaitu membawa anak pada keselamatan pribadi, pada kebijaksanaan, sukacita, penerangan dan kemurnian. Orang tua dapat mengajarkan Firman Allah kepada anak melalui berbagi fakta-fakta yang ada dalam Alkitab baik berapa banyak kitab, siapa yang menulis, dan sebagainya. Cara lain yang dapat diajarkan adalah dengan menjelaskan informasi yang terdapat dalam teks Alkitab. Sedangkan cara yang paling mendalam adalah dengan mengajarkan kebenaran rohani ataupun prinsip-prinsip yang terdapat dibalik semua cerita Alkitab. Ketika Firman Allah menjadi prinsip bagi kehidupan anak-anak, 
maka anak akan tumbuh menjadi kuat di dalam roh dan karakter. Melalui Firman Allah, anak-anak juga mampu mengambil keputusan yang benar sebagaimana prinsip Firman Allah yang telah diajarkan.

Teladan. Orang tua yang mengasihi anaknya akan memberi teladan tentang bagaimana anak harus hidup dengan menumbuhkan kepercayaan diri mereka (Kasiati \& Keriapy, 2020). Keteladanan bagaikan peta jalan dimana orang tua akan menunjukkan arahnya dan anak akan menentukan arah kehidupannya sendiri. Meskipun demikian kemungkinan besar orang tua akan melihat perilaku dan jalan pikirannya pada diri anak dalam perjalanan hidupnya sebab keteladananlah yang mampu menginspirasi anak. Keseimbangan antara pengajaran dengan keteladanan yang sama baiknya akan menjadikan anak berkepribadian baik dan taat pada orang tua. Sebaliknya apabila keteladanan tidak ditunjukkan maka dapat menimbulkan kebencian dan kemarahan.

Charles Swindol dalam Wiriadinata mengatakan bahwa membesarkan anak sama dengan memuridkan mereka (Wiriadinata, 2014, p. 97). Memuridkan berkaitan dengan menjadikan kehidupan seseorang semakin serupa dengan Kristus. Yesus memberikan teladan kehidupan yang berkenan kepada Allah baik dalam perkataan maupun perbuatan. Rasul Paulus mengatakan "Jadilah pengikutku, sama seperti aku juga menjadi pengikut Kristus" (1 Korintus 11:1). Rasul Paulus tidak takut untuk menyuruh orang-orang memeriksa hidupnya untuk melihat apakah ia berbuat sesuai dengan yang ia ajarkan. Demikian juga orang tua, jika ingin melihat anakanak hidup semakin serupa seperti Kristus, maka orang tua harus berani untuk menjadi teladan bagi anak-anak.

Hasil penelitian menunjukkan orang tua menyadari bahwa didikan dari orang tua saat ini akan membawa pengaruh pada kepribadian dan iman kehidupan anak di masa yang akan datang. Sebagian besar orang tua beranggapan bahwa tugas mendidik anak tidak bisa serta merta diberikan kepada orang lain, karena orang tua menyadari bahwa dimungkinkan pola asuh orang tua berbeda dengan orang lain, sehingga bisa membentuk kepribadian anak yang berbeda. Sedangkan, sebagian kecil orang tua menyadari bahwa tanggung jawab mengasuh anak bisa diberikan kepada pihak lain (selain orang tua) jika orang tua tidak sanggup mengasuh.

Berkenaan dengan jenis pola asuh orang tua, sebagian besar orang tua menerapkan pola asuh demokratis. Hal itu terbukti dengan sikap orang tua yang tidak pernah memaksakan anak untuk mencapai apa yang menjadi tuntutan orang tua, tidak langsung memenuhi permintaan anak yang tidak dibutuhkan, memiliki waktu dan melakukan aktifitas saat berkumpul 
dengan keluarga termasuk untuk berbincang-bincang serta mendengarkan pendapat anak. Dalam pola asuh ditemukan adanya hambatan dari orang tua yaitu ketidakseimbangan pola asuh yang diberikan kepada anak, karena adanya ketidaksepakatan dalam mengambil keputusan.

Berkenaan dengan pola asuh, orang tua juga memberikan unsur-unsur penting lainnya. Unsur pertama adalah kasih. Sebagian besar orang tua menyadari bahwa anak adalah anugerah dari Tuhan dan menerima keberadaan anak saat anak lahir ke dalam dunia. Semua orang tua mengasihi anaknya dengan ditunjukkan melalui kata-kata, sentuhan fisik, memberikan waktu untuk mendengarkan anak, dan memberi hadiah kepada anak sebagai bentuk menanamkan identitas yang kuat pada diri anak.

Unsur kedua adalah disiplin. Sebagian besar orang tua memberikan disiplin kepada anak melalui peraturan rumah. Orang tua mendisiplin anak supaya membentuk kepribadian anak yang terarah dan teratur sehingga menjadi menjadi sukses di masa depan. Semua orang tua memberikan tindakan kedisiplinan pada waktu yang tepat.

Unsur ketiga adalah pengajaran. Semua orang tua memberikan pengajaran kepada anak dengan motivasi yang berbeda-beda. Motivasi yang dimiliki orang tua antara lain mendukung keputusan anak menerima Tuhan Yesus Kristus secara pribadi, mempersiapkan diri anak menghadapi masa kini dan mendatang, nilai-nilai Kristen adalah suatu hal yang benar, agar perilaku anak sesuai dengan Firman Tuhan, menyadari bahwa Tuhan adalah pemilik hidup orang Kristen, dan melaksanakan tanggung jawab yang diberikan Tuhan kepada orang tua. Orang tua memberikan pengajaran kepada anak melalui berbagai cara yaitu mezbah keluarga, kehidupan sehari-hari dan kegiatan membaca Firman Tuhan bersama anak yang diajarkan sejak kecil.

Unsur keempat adalah teladan. Sebagian besar orang tua telah memberikan teladan kepada anak melalui perbuatan dan perkataan. Orang tua memberikan teladan kepada anak dengan beberapa alasan yaitu karena anak cenderung meniru tindakan orang tua, pengajaran yang diberikan harus disertai keteladanan, keinginan orang tua supaya anak menjadi pribadi yang sungguhsungguh takut akan Tuhan, dan anak membutuhkan figur yang dapat ditiru.

\section{KESIMPULAN}

Dari penelitian ini dapat disimpulkan bahwa: 1) Gambaran keterampilan sosial anak generasi alfa di GBI Banyumanik Semarang. Sebagian besar anak telah memiliki keterampilan 
sosial terhadap diri sendiri, orang lain, dan keberhasilan akademik. Sedangkan keterampilan sosial terhadap lingkungan rumah masih minim, hal ini disebabkan karena kurangnya kesadaran anak dalam menjaga kebersihan. 2) Pola asuh orang tua anak generasi alfa di GBI Banyumanik, sebagian besar orang tua menyatakan bahwa pola asuh penting bagi anak karena akan membawa pengaruh pada kepribadian dan iman kehidupan anak di masa yang akan datang. Sebagian besar orang tua menerapkan pola asuh demokratis yang di dalamnya meliputi kasih, disiplin, pengajaran, dan teladan.

Rekomendasi atas penelitian ini adalah agar orang tua bersepakat dalam menerapkan pola asuh bagi anak, agar anak tidak merasa bingung atau memihak kepada salah satu pengasuhan ketika orang tua menunjukkan perbedaan. Orang tua perlu menerapkan pola asuh demokratis bagi anak yang di dalamnya ada unsurunsur penting yaitu kasih, disiplin, pengajaran, dan teladan.

Dalam penelitian ini ditemukan beberapa faktor lain yang mempengaruhi keterampilan sosial anak. Peneliti selanjutnya diharapkan dapat melakukan penelitian terkait faktor yang mempengaruhi keterampilan sosial anak. Disamping itu dalam perlu melakukan penelitian terkait keterampilan sosial anak di era new normal.

\section{DAFTAR PUSTAKA}

Agusniatih, Andi, \& Monepa, J. M. (2019).

Ketrampilan Sosial Anak Usia Dini.

Edu Publisher.

Baskoro, D. (2019). Menjadi Lebih Baik:

Parenting Healing (1st ed.). Elex Media Komputindo.

Darmadi, H. (2019). Pengantar Pendidikan Era Globalisasi: Konsep

Dasar, Teori, Strategi, dan Implementasi dalam Pendidikan Globalisasi (R. M. S. Putra (ed.)). An1mage.

Darmawan, I. P. A. (2019). Pembelajaran Memorisasi Dalam Ulangan 6:6-9. EPIGRAPHE: Jurnal Teologi Dan Pelayanan Kristiani, 3(1), 21. https://doi.org/10.33991/epigraphe.v $3 \mathrm{i} 1.50$

Fadlurrohim, I., Husein, A., Yulia, L., Wibowo, H., \& Raharjo, S. T. (2020). Memahami Perkembangan Anak Generasi Alfa Di Era Industri 4.0. Focus : Jurnal Pekerjaan Sosial, 2(2), 178.

https://doi.org/10.24198/focus.v2i2.2 6235

Harmadi, M., \& Karnawati. (2020). Kurikulum Pendidikan Agama Kristen: Lintasan Menuju Iman yang Purna. Vieka Wahana Semesta.

Hurlock, E. B. (1997). Psikologi Perkembangan: Suatu Pendekatan 
Sepanjang Rentang Kehidupan.

Erlangga.

Irawan, H., Yahya, K., Tanbunaan, G. I., \& dkk. (2018). Dinamika Spiritualitas: Generasi Muda Kristen Indonesia. Yayasan Bilangan Research Center.

Karnawati, Hosana, \& Darmawan, I. P. A. (2019). Lingkungan Proses Pembelajaran Yesus. Veritas Lux Mea: Jurnal Teologi Dan Pendidikan Kristen, 1(2). https://jurnal.sttkn.ac.id/index.php/V eritas/article/view/48/pdf

Karnawati, K., \& Darmawan, I. P. A. (2020). Tahapan Pembelajaran Yesus pada Perempuan Samaria. Davar Jurnal Teologi, 1(1), 9-18. http://ejournalsangkakala.ac.id/index.php/DJ T/article/view/4

Karnawati, \& Suseno, A. (2021). Mewartakan Injil pada Anak Usia 0-2 Tahun Menggunakan Metode Pembacaan Alkitab Secara Nyaring di Masa Pandemi. KHARISMATA: Jurnal Teologi Pantekosta, 3. https://www.ejournal.stajember.ac.id/index.php/kh arismata/article/view/58/pdf

Kasiati, R. I., \& Keriapy, F. (2020). ANTUSIAS: Jurnal Teologi dan Pelayanan. 6(2), 121-134. https://www.sttintheos.ac.id/ejournal/index.php/antusias/article/vie $\mathrm{w} / 617 / 218$
Kementrian Pendidikan dan Kebudayaan. (2018). Seri Pendidikan Orang Tua: Mendidik Anak di Era Digital. Kementrian Pendidikan dan Kebudayaan.

Kementrian Pendidikan dan Kebudayaan. (2019). Modul Mendidik Anak di Era Digital. Kementrian Pendidikan dan Kebudayaan.

Kurniati, E. (2016). Permainan Tradisional dan Perannya dalam Mengembangkan Keterampilan Sosial. Prenadamedia Group.

Laible, D. J., Carlo, G., \& Padilla-Walker, L. M. (2019). “The Oxford Handbook of Parenting and Moral Development." Oxford University Press.

Manurung, K. (2021). Mencermati Arti Penting Penggunaan Bahasa Cinta Anak dalam Keluarga Kristen di Era 5.0. EDULEAD: Journal of Christian Education and Leadership, 2(1), 5370.

https://doi.org/10.47530/edulead.v2i1 .53

McCrindle. (2020). Why We Named Them Gen Alpha. Mccrindle.Com.Au. https://mccrindle.com.au/insights/blo garchive/why-we-named-them-genalpha/

Merrell, K. W., \& Gimpel, G. A. (2014). Social Skill of Children and Adolescents. Psychology Press. 
Musman, A. (2020). Seni Mendidik Anak 4.0. Psikologi Corner.

Rantesalu, S. B. (2018). Kompetensi Pedagogik Menurut Analisis Ulangan 6:7-9 dengan Pendekatan Hermeneutik Schleiermacher. BIA': Jurnal Teologi Dan Pendidikan Kristen Kontekstual, 1(2), 153-163. https://doi.org/10.34307/b.v1i2.14

Rohimin, R. (2020). Reposisi Pendidikan Keluarga Bagi Anak Generasi Alfa. Nuansa, 12(2), 152-172. https://doi.org/10.29300/nuansa.v12i 2.2765

Santosa, E. T. (2015). Raising Children in Digital Era. Elex Media Komputindo. Santoso, E. (2017). Millenial Finance (1st ed.). Grasindo.

Susanto, A. (2015). Bimbingan dan Konseling di Taman Kanak-kanak. Prenadamedia Group.

Tfuakani, A., Otta, P., Tinggi, S., \& Victory, T. (2021). BAGI ANAK GENERASI ALFA. Voice of HAMI Jurnal Teologi Dan Pendidikan Agama Kristen, 4(1), 12-26. http://stthami.ac.id/ojs/index.php/ha mi/article/view/37/29

Tridhonanto, A., \& Agency, B. (2014). Mengembangkan Pola Asuh Demokratis. Elex Media Komputindo.

Wiriadinata, S. (2014). Orang Tua Idaman: Memahami Harapan Anak terhadap Orang Tua. Lembaga Literatur Baptis. 